\title{
PENENTUAN LAHAN PERTANIAN PANGAN BERKELANJUTAN (LP2B) MENGGUNAKAN METODE MULTI DATA SPASIALI DI KECAMATAN NGADIROJO, KABUPATEN PACITAN
}

\author{
Muhammad Taufik*1, Akbar Kurniawan,Fany Maya Pusparini \\ Departemen Teknik Geomatika, FTSLK-ITS, Kampus ITS Sukolilo, Surabaya, 60111, Indonesia \\ e-mail: *1taufik_srmd@yahoo.com
}

\begin{abstract}
Abstrak
Indonesia merupakan negara dengan tingkat kesuburan di atas rata-rata, karenanya banyak wilayah yang cukup potensial digunakan sebagai lahan pertanian pangan. Namun terjadi cepatnya konversi lahan pertanian menjadi lahan non-pertanian yang merupakan ancaman terhadap ketahanan dan keamanan pangan. Didasari hal tersebut perlu dilakukan penetapan Kawasan Lahan Pertanian Pangan Berkelanjutan yang terbagi dalam bentuk Lahan Pertanian Pangan Berkelanjutan (LP2B) dan Lahan Cadangan Pertanian Pangan Berkelanjutan (LCP2B).Penentuan LP2B dan LCP2B menggunakan teknologi penginderaan jauh berupa citra satelit resolusi tinggi teknologi Sistem Informasi Geografis (SIG). Penelitian ini dilakukan di Bagian Wilayah Perkotaan (BWP) Kecamatan Ngadirojo, Kabupaten Pacitan. Dari analisa kebutuhan dan ketersediaan pangan, serta kesesuaian hasil identifikasi yang ada dalam rencana pola ruang wilayah, diperoleh areal LP2B seluas 322,159 Ha dan LCP2B seluas 204,466 Ha
\end{abstract}

Kata kunci : Alih Fungsi Lahan Pertanian, Analisa Spasial, Overlay, Skoring, LP2B, LCP2B.

\begin{abstract}
Indonesia has high fertility rate, consequently there are many potential areas to be used as a food agricultural land. However, the rapid conversion of agricultural land to non-agricultural is a threat to food security. Based on those problem, it is necessary to determine Sustainable Agricultural Food Land Area by divided into Sustainable Food Agricultural Land (LP2B) and Sustainable Food Agricultural Reserve Land (LCP2B). Determination of LP2B and $\angle C P 2 B$ was done using remote sensing technology in the form of high resolution satellite imagery and using Geographic Information System (GIS). This research was conducted in the Urban Area Section (BWP) of Ngadirojo District, Pacitan Regency. The analysis used are the analysis of food needs and its availability, the determination of $\angle P 2 B$ and $L C P 2 B$ areas, and the suitability of $\angle P 2 B$ and $\angle C P 2 B$ identification results in the spatial regional planning. The final result of this research is LP2B area equal to 322,159 Ha and LCP2B area equal to 204,466 Ha in Urban Area Section Ngadirojo District, Pacitan Regency.
\end{abstract}

Keywords - Conversion of Agricultural Land, Spatial Analysis, Overlay, Scoring, LP2B, LCP2

\section{PENDAHULUAN}

Indonesia merupakan negara dengan tingkat kesuburan di atas rata-rata, karenanya banyak wilayah yang cukup potensial digunakan sebagai lahan pertanian pangan. Namun dalam realitanya menunjukkan bahwa sektor pertanian khususnya pertanian tanaman pangan dihadapkan pada berbagai masalah, di antaranya cepatnya konversi lahan pertanian menjadi non pertanian yang berimbas pada sempitnya lahan pertanian per kapita penduduk Indonesia (900 m2/kapita), serta tidak amannya status penguasaan lahan.

Regulasi tentang alih fungsi lahan harus dijalankan secara ketat, terkontrol mulai tingkat pusat sampai ke daerah. Sebab apabila tidak dilaksanakan diperkirakan tahun 2025 nanti luas lahan sawah di Indonesia hanya akan tersisa dua juta hektar[2]. Maka dari itu perlu adanya upaya Penyelamatan Lahan Pertanian Pangan, baik yang sudah ada atau cadangannya. Hal tersebut perlu ditindaklanjuti dengan mengidentifikasi lahan pertanian yang ada saat ini baik yang beririgasi dan tidak beririgasi dalam bentuk Lahan Pertanian Pangan Berkelanjutan (LP2B) dan Lahan Cadangan Pertanian Pangan Berkelanjutan (LCP2B).

Kecamatan Ngadirojo yang ada di Kabupaten Pacitan merupakan wilayah perkotaan dan saat ini 
dapat dikatakan sebagai lumbung padi bagi wilayah kecamatan khususnya dan kabupaten pada umumnya. Melihat perkembangan wilayah kota dan semakin pentingnya kedudukan kota dalam pembangunan wilayah, maka kecenderungan alih fungsi lahan pertanian akan semakin terbuka. Didasari hal tersebut diatas perlu dilakukan penetapan LP2B berdasarkan data lahan pertanian serta kesesuaian hasil pemetaan di Kabupaten Pacitan.

Hasil identifikasi LP2B dijadikan bahan kajian kesesuaian pola ruang wilayah pada Rencana Detail Tata Ruang (RDTR) Kecamatan Ngadirojo, Kabupaten Pacitan untuk memberikan masukan dalam penetapan LP2B yang dilindungi dan dikembangkan secara konsisten.

\section{METODE}

Lokasi penelitian ini mengambil studi kasus di Kecamatan Ngadirojo, Kabupaten Pacitan. Terletak pada koordinat geografis antara $8^{0}$ $06^{\prime} 42^{\prime \prime}$ - $8^{0} 15^{\prime} 56,1^{\prime \prime}$ Lintang Selatan dan $111^{\circ}$ $16^{\prime} 03,1^{\prime \prime}$ - $111^{0} 21^{\prime} 50,4^{\prime \prime}$ Bujur Timur seperti ditunjukkan pada gambar berikut :
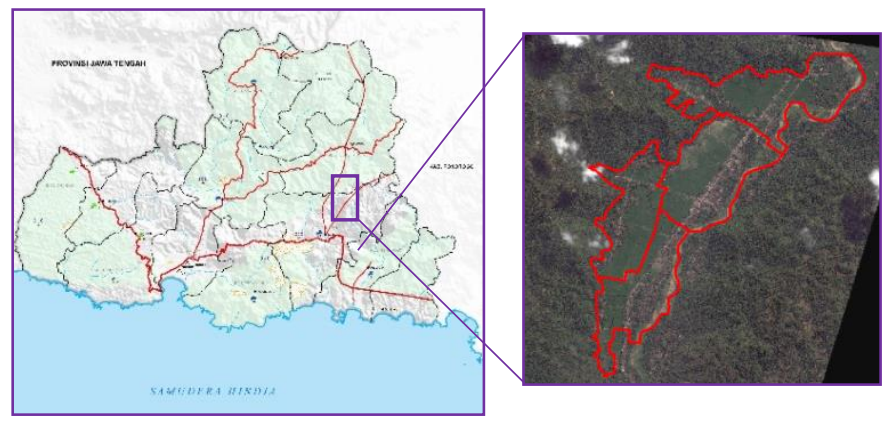

Gambar 1. Lokasi Penelitian Kecamatan Arjosari

Pengembangan Peta Lahan Pertanian Pangan Berkelanjutan (LP2B) menggunakan analisa spasial berupa skoring dan buffering (Subroto dan Susetyo,2016) dari berbagai data spasial dasar, berupa data tutupan lahan, jenis tanah, kelerengan, irigasi,curah hujan. Ditambahkan data tabular berupa data curah hujan, dan produktivitas lahan .

\section{HASIL DAN PEMBAHASAN}

Karakter Kelerangan dan ketinggian wilayah

Analisa spasial dengan cara interpolasi garis kontur yang kemudian menghasilkan 2 parameter yaitu kelerengan dan ketinggian. Dari data raster kontur, kemudian dilakukan reklasifikasi menjadi 4 kelas sesuai acuan parameter untuk menghasilkan peta ketinggian. Sedangkan untuk membuat Peta Kelerengan (slope), dilakukan dengan create slope dari data kontur, kemudian dilakukan reklasifikasi dan skoring menjadi 4 kelas sesuai acuan parameter.

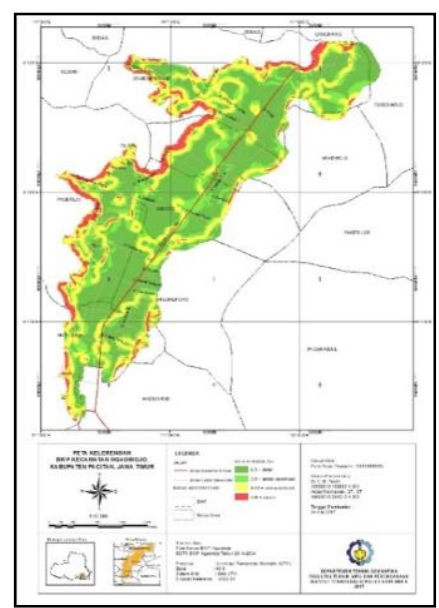

Gambar 2. Peta Kelerengan BWP Ngadirojo

Kelerengan di wilayah BWP Ngadirojo lebih dari mencakup lebih $30 \%$ dari wilayah dengan tutupan lahan berupa sawah, memiliki ketinggian berkisar 0-3\%. Hal tersebut menunjukkan bahwa wilayah persawahan di BWP Ngadirojo sangat potensial untuk ditetapkan sebagai LP2B.

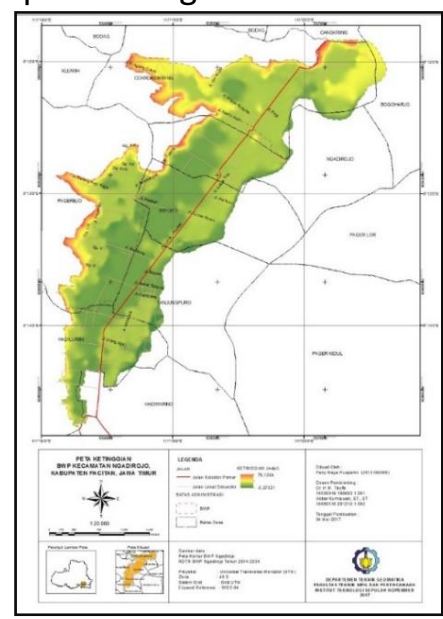

Gambar 3. Peta Ketinggian BWP Ngadirojo 
Seluruh wilayah penelitian memiliki ketinggian berkisar antara 0-100 $\mathrm{m} \mathrm{dpl}$; wilayah ini dapat dikategorikan sangat potesial untuk dijadikan LP2B di Kabupaten Pacitan dengan skor ketinggian sebesar 1 .

\section{Curah Hujan}

Data curah hujan rata - rata selama 3 tahun terakhir, yakni tahun 2014, 2015, 2016. Hasil interpolasi berupa data curah hujan dengan format raster, kemudian dilakukan reklasifikasi dan skoring menjadi 4 kelas sesuai dengan acuan. Berikut hasil dari interpolasi data curah hujan:

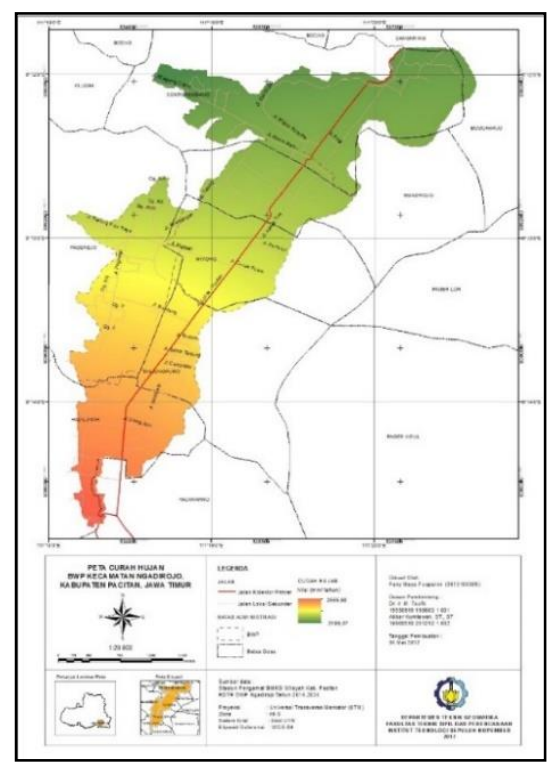

Gambar 4. Peta Curah Hujan BWP Ngadirojo

Pada wilayah penelitian dapat dilihat bahwa sebaran jumlah curah hujan seluruhnya diatas $2000 \mathrm{~mm} /$ th dengan variasi antara 2199,87 $2555,68 \mathrm{~mm} / \mathrm{th}$. Hal tersebut menunjukkan bahwa curah hujan di BWP Ngadirojo tergolong tinggi. Maka daerah studi penelitian dari segi curah hujan dapat dikategorikan sangat potesial untuk dijadikan LP2B.

\section{Jenis Tanah}

Untuk jenis tanah di BWP NGadirojo, dilakukan proses klasifikasi berdasarkan kepekaan terhadap erosi, tekstur, kedalaman tanah, dan $\mathrm{pH}$ sesuai dengan acuan yang digunakan. Hasil dari klasifikasi dan skoring jenis tanah yang didapatkan yaitu 4 kelas.Sebagian besar wilayah BWP Ngadirojo merupakan jenis tanah Aluvial, dimana tanah ini memiliki potensi yang sangat baik untuk digunakan sebagai lahan pertanian pangan. Selain itu sebaran tanah aluvial mayoritas terdapat di wilayah persawahan, sehingga dari segi jenis tanah untuk kesesuaian lahan pertanian dapat dikategorikan layak untuk dijadikan LP2B di BWP Ngadirojo.

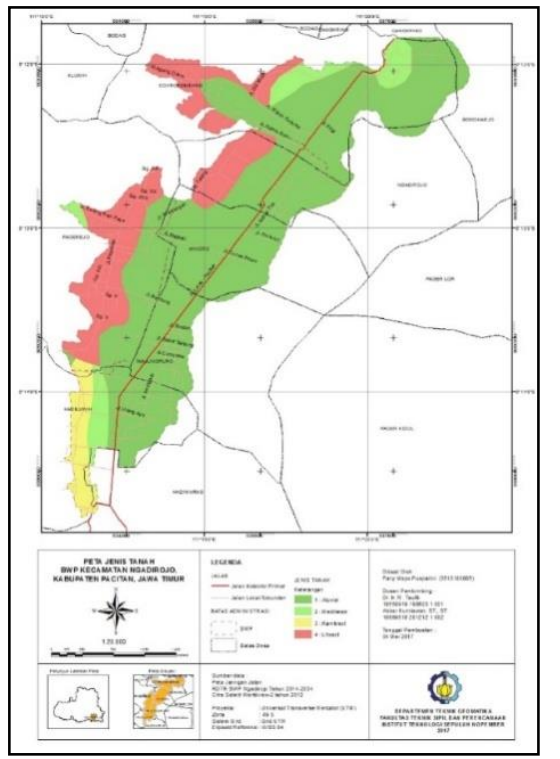

Gambar 5. Peta Jenis Tanah BWP Ngadirojo

Citra Satelit

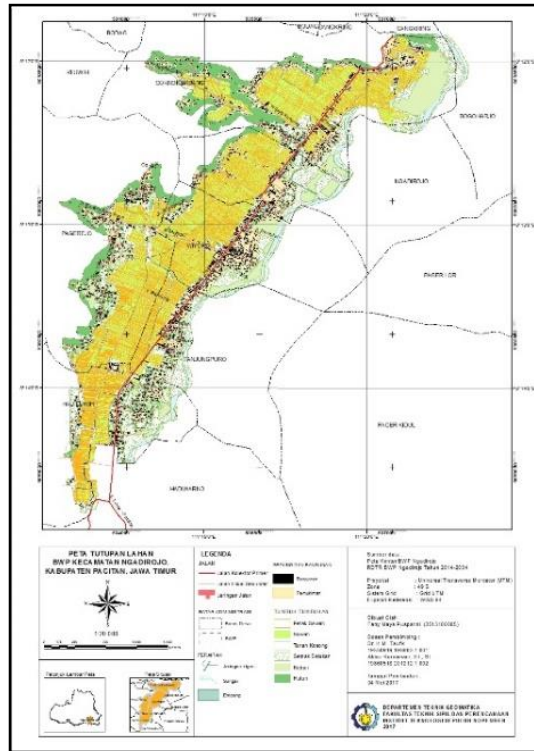

Gambar 6. Tutupan Lahan BWP Ngadirojo

Citra yang digunakan telah terokthorektifikasi dan dilakukan interpretasi manual dengan metode on screen digitizing untuk menghasilkan peta garis tutupan lahan. Kemudian dilakukan proses groundtruth serta uji akurasi hasil interpretasi dengan hasil akurasi $>85 \%$. 
Dari hasil interpretasi manual, diperoleh hasil tutupan lahan berjumlah 8 kelas, yakni bangunan, permukiman, jalan, sawah, kebun, semak belukar, tanah kosong, sungai. Hasil groundtruth menggunakan data 30 sampel, diperoleh 28 sampel sesuai dan 2 sampel tidak sesuai. Sehingga uji ketelitian interpretasi citra sebesar 93,3\%. Hal ini menunjukkan bahwa hasil interpretasi manual sesuai dengan data di lapangan.

\section{Jaringan Irigasi}

Jaringan irigasi hasil digitasi peta skala 1:5000. data jaringan irigasi berupa peta garis .

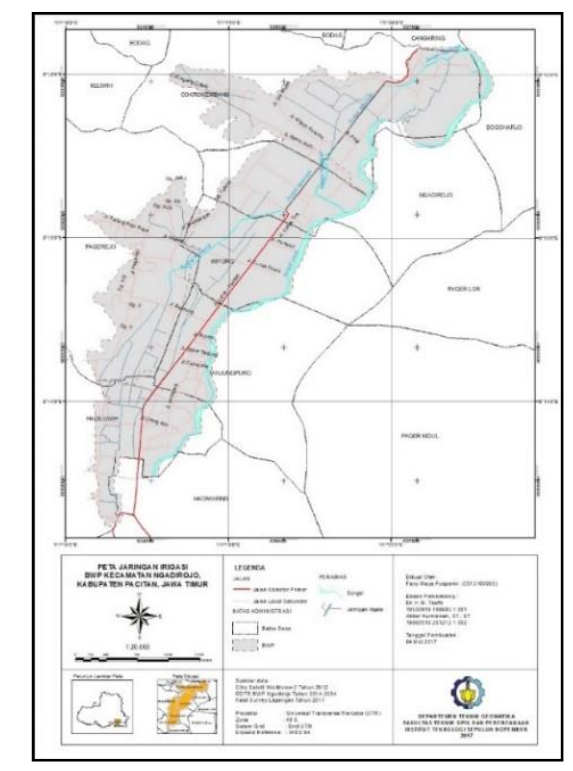

Gambar 7. Jaringan Irigasi BWP Ngadirojo

Seluruh wilayah BWP Ngadirojo teraliri jaringan irigasi teknis. Berdasarkan data dari Dinas Bina Marga dan Pengairan bahwa daerah studi umumnya setiap tahun mendapatkan pengembangan pengairan baik untuk pengembangan dam maupun embung untuk mengantisipasi terjadinya musim yang selalu berubah-rubah setiap tahunnya.

\section{Jaringan Jalan}

Peta jaringan jalan yang diperoleh berupa data raster dengan skala 1:5000. Selanjutnya dilakukan digitasi untuk menghasilkan data jaringan akses jalab berupa peta garis. Kemudian dilakukan analisa spasial dengan nilai batas pada jarak $50 \mathrm{~m}$ dan $100 \mathrm{~m}$ dari badan jalan, selanjutnya dilakukan klasifikasi dan skoring dengan hasil 2 kelas sesuai acuan yang ada. . Lahan persawahannya di daerah Ngadirojo sudah dilalui jaringan utama dan local dan kondisi akses baik; dengan demikian untuk distribusi menuju lahan persawahan tidak mengalami kesulitan jalan antar lahan persawahan didukung oleh jaringan jalan usaha tani (JUT). Dari persebaran jalan tersebut, dilakukan skoring dengan nilai jarak $50 \mathrm{~m}$ dan diatas jarak $50 \mathrm{~m}$ dari badan jalan. Hal ini berpengaruh pada keberlanjutan lahan lahan pertanian, semakin dekat dengan badan jalan, maka potensi konversi lahan pertanian semakin besar, begitu juga sebaliknya.

\section{Pembobotan}

Bobot variabel yang digunakan dalam penelitian ini mengacu pada hasil pembobotan yang dilakukan oleh Gatot Subroto (2016], dengan modifikasi pada jumlah variabel yang digunakan.

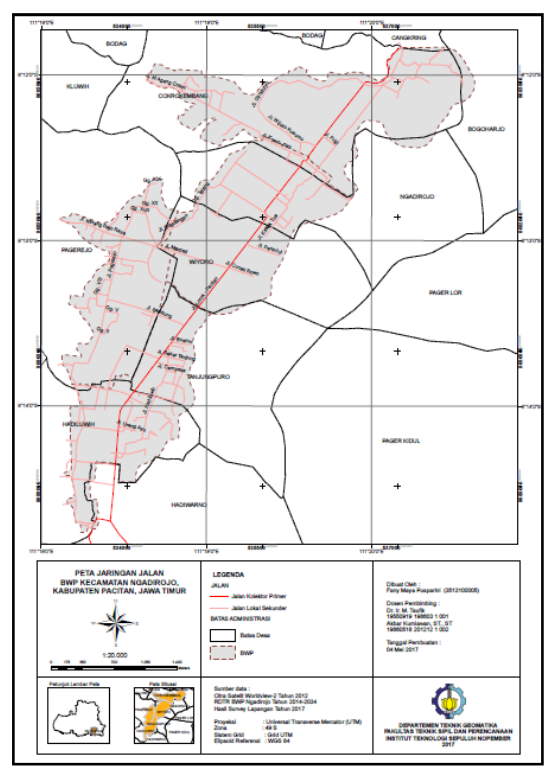

Gambar 8. Peta Jaringan Jalan BWP Ngadirojo

Berikut merupakan hasil modifikasi variabel penentuan LP2B dan LCP2B:

Tabel 1. Variabel LP2B dan LCP2B

\begin{tabular}{|c|c|c|c|}
\hline Variabel LP2B & Bobot & Variabel LCP2B & Bobot \\
\hline Produktifitas & 0,573 & Produktifitas & 0,573 \\
\hline $\begin{array}{l}\text { Ketersediaan } \\
\text { Air }\end{array}$ & 0,549 & $\begin{array}{l}\text { Ketersediaan } \\
\text { Air }\end{array}$ & 0,7225 \\
\hline Variabel LP2B & Bobot & Variabel LCP2B & Bobot \\
\hline IP & 0,347 & $\begin{array}{l}\text { Hamparan } \\
\text { Lahan }\end{array}$ & 0,2775 \\
\hline $\begin{array}{l}\text { Hamparan } \\
\text { Lahan }\end{array}$ & 0,104 & $\begin{array}{l}\text { Kemampuan } \\
\text { Lahan }\end{array}$ & 0,262 \\
\hline Total & 1 & Jenis Tanah & 0,31725 \\
\hline Kemampuan & 0,262 & Curah Hujan & 0,29925 \\
\hline
\end{tabular}




\begin{tabular}{llll}
\hline $\begin{array}{l}\text { Lahan } \\
\text { Jenis Tanah }\end{array}$ & 0,31725 & Kelerengan & 0,21925 \\
$\begin{array}{l}\text { Curah Hujan } \\
\text { Kelerengan }\end{array}$ & 0,29925 & Ketinggian & 0,16525 \\
& 0,21925 & $\begin{array}{l}\text { Infrastruktur } \\
\text { Dasar }\end{array}$ & 0,165 \\
Ketinggian & 0,16525 & Sistem Irigasi & 0,854 \\
Total & 1 & Akses Jalan & 0,146 \\
Infrastruktur & 0,165 & Infrastruktur & 0,165 \\
Dasar & & Dasar & \\
Sistem Irigasi & 0,854 & Sistem Irigasi & 0,854 \\
Akses Jalan & 0,146 & Akses Jalan & 0,146 \\
Total & 1 & Total & 1 \\
\hline
\end{tabular}

Proses pembobotan dilakukan terhadap hasil penggabungan secara tumpang susun seluruh parameter dengan menggunakan rumus :

$\mathrm{N}=\mathrm{S} 1 * \mathrm{~B} 1+\mathrm{S} 2 * \mathrm{~B} 2+\ldots . .+\mathrm{Sn} * \mathrm{Bn}$

Dengan:

$\mathrm{N}$ : Nilai

Sn : Skor Variabel ke-n

$\mathrm{Bn}$ : Bobot Variabel ke-n

Berikut merupakan hasil dari pembobotan :

Tabel 2. Hasil Klasifikasi LP2B

\begin{tabular}{|c|c|c|c|c|}
\hline Aspek & Skor & Bobot & $\begin{array}{c}\text { Hasil } \\
\text { Perhitungan }\end{array}$ & Klasifikasi \\
\hline \multicolumn{5}{|c|}{ 1) Produktivitas } \\
\hline Ketersediaan & 1 & 0,549 & 1,347 & $1: 1,347$ \\
\hline Air & & & 1,555 & $2: 1,555$ \\
\hline IP & 2 & 0,347 & & \\
\hline $\begin{array}{l}\text { Hamparan } \\
\text { Lahan }\end{array}$ & 1,3 & 0,104 & & \\
\hline \multicolumn{5}{|c|}{ 2) Kemampuan Lahan } \\
\hline Jenis Tanah & $1,2,3$ & 0,31725 & $1.001-1,966$ & $1: 1,001-$ \\
\hline Curah Hujan & 1 & 0,29925 & & 1,4395 \\
\hline Kelerengan & $1,2,3$ & 0,21925 & & 2: \\
\hline Ketinggian & 1 & 0,16525 & & $\begin{array}{c}1,5375- \\
1,966\end{array}$ \\
\hline \multicolumn{5}{|c|}{ 3) Infrastruktur Dasar } \\
\hline Sistem Irigasi & 1 & 0,854 & 1 & $1: 1$ \\
\hline Akses Jalan & 1,2 & 0,146 & 1,146 & $2: 1,146$ \\
\hline
\end{tabular}

Dari hasil klasifikasi LP2B terbaru tersebut dikalikan dengan bobot aspek utama LP2B, diperoleh hasil skor sebagi berikut:

1 (sangat potensial) $=1$

2 (potensial) $\quad=1,165-2$

Hasil perhitungan LCP2B adalah sebagai berikut:
Tabel 3. Hasil Klasifikasi LCP2B

\begin{tabular}{lcccc}
\hline \multicolumn{1}{c}{ Aspek } & Skor & Bobot & $\begin{array}{c}\text { Hasil } \\
\text { Perhitungan }\end{array}$ & Klasifikasi \\
\hline $\begin{array}{l}\text { 1) Produktivitas } \\
\text { Ketersediaan }\end{array}$ & 1 & 0,549 & 1 & $1: 1$ \\
$\begin{array}{l}\text { Air } \\
\text { Hamparan }\end{array}$ & 1 & 0,104 & & \\
$\begin{array}{l}\text { Lahan } \\
\text { 2) Kemampuan Lahan }\end{array}$ & & & \\
Jenis Tanah & $1,2,3$ & 0,31725 & & $1: 1,001-$ \\
$\begin{array}{l}\text { Curah Hujan } \\
\text { Kelerengan }\end{array}$ & $1,2,3$ & 0,29925 & & 1,4395 \\
Ketinggian & 1 & 0,21925 & $1.001-1,966$ & $2:$ \\
3) Infrastruktur Dasar & & & $1,5375-$ \\
Sistem & 1 & 0,854 & 1 & 1,966 \\
Irigasi & 1 & 0,146 & & $1: 1$ \\
Akses Jalan & 1 & & \\
\hline
\end{tabular}

Dari hasil klasifikasi LP2B terbaru tersebut dikalikan dengan bobot aspek utama LP2B, diperoleh hasil skor sebagai berikut:

1 (sangat potensial $\quad)=1 ;$

2 (potensial) $\quad=1,262$

Dengan hasil pembobotan baru tersebut maka diperoleh hasil luasan sebaran wilayah

$$
\begin{aligned}
& \text { - untuk LP2B } \\
& \text { Skor 1: 155,281 Ha dan } \\
& \text { Skor } 2 \text { : 179,878 Ha, } \\
& \text { - untuk LCP2B } \\
& \text { skor 1: 200,796 Ha, dan } \\
& \text { skor } 2: 17,510 \mathrm{Ha} \text {. }
\end{aligned}
$$

Dari hasil tersebut, secara spasial sebaran lahan untuk LP2B dan LCP2B di wilayah BWP Kecamatan Ngadirojo, Pacitan sebagai berikut :

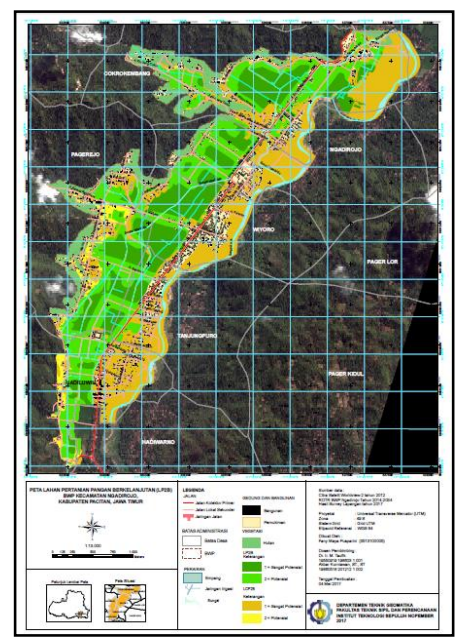

Gambar 9. Peta Sebaran LP2B 
Wilayah LP2B sangat potensial tersebar di Desa Cokrokembang, Hadiluwih, Ngadirojo, Pagerejo dan Tanjungpuro. Lahan tipe ini merupakan lahan produktif dan relatif datar dengan kemiringan lereng dibawah $8 \%$,memiliki jenis tanah Aluvial dan Mediteran, hamparan lahan $>5 \mathrm{Ha}$, serta berjarak lebih dari $50 \mathrm{~m}$ dari badan jalan. Hal ini menunjukkan bahwa lahan tersebut relatif mudah untuk dipertahankan karena semakin jauh dari badan jalan, maka potensi dialih fungsikan wilayah tersebut kecil karena aksesbilitas yang kurang.

Wilayah LP2B potensial tersebar di Desa Cokrokembang, Hadiluwih, Hadiwarno, Ngadirojo, Pagerejo dan Tanjungpuro. Lahan tipe ini merupakan lahan produktif, kemiringan lereng yang bervariasi antara $8-30 \%$,topografi yang relatif datar, memiliki jenis tanah Mediteran, Kambisol, dan Litosol serta berjarak tidak lebih dari $50 \mathrm{~m}$ dari badan jalan. Hal ini menjadi daya tarik tersendiri bagi investor maupun pengembang properti untuk menjadikan kawasan tersebut untuk kawasan pemukiman ataupun perekonomian karena wilayahnya strategis. Sehingga lahan LP2B potensial ini memiliki potensi yang tinggi pula untuk terkonversi.

Wilayah LCP2B yang sangat potensial tersebar seluruh wilayah BWP Ngadirojo. Lahan tipe ini merupakan lahan yang relatif datar dengan kemiringan lereng dibawah 8\%, memiliki jenis tanah Aluvial dan Mediteran, hamparan lahan juga $>5 \mathrm{Ha}$, memiliki jaringan irigasi dan jaringan jalan, dan untuk wilayah LCP2B yang potensial tersebar di Desa Pagerejo dan Hadiluwih. Lahan tipe ini merupakan lahan yang memiliki kelerengan berkisar 8-30\%, memiliki jenis tanah Kambisol, serta memiliki jaringan irigasi dan jaringan jalan.

\section{KESIMPULAN}

Berdasarkan hasil analisis yang telah dilakukan pada pembahasan sebelumnya, maka dapat diperoleh kesimpulan dari penelitian ini adalah:

- Lahan LP2B totalnya 322,159 Ha, dengan rincian LP2B sangat potensial seluas 155,281 Ha dan LP2B potensial seluas $179,878 \mathrm{Ha}$.

- Lahan LCP2B totalnya 218,306 Ha, dengan rincian LCP2B sangat potensial seluas 200,796 $\mathrm{Ha}$ dan LCP2B potensial seluas 17,510 $\mathrm{Ha}$.

\section{DAFTAR PUSTAKA}

Badan Pusat Statistik. 2015. Pacitan Dalam Angka. Pacitan : Badan Pusat Statistik Kabupaten Pacitan

Republik Indonesia. 2009. Undang-undang No. 41 Tahun 2009 Tentang Perlindungan Lahan Pertanian Berkelanjutan. Jakarta : Sekretariat Negara.

Republik Indonesia. 2013. Peraturan Menteri Pertanian Nomor 79 Tahun 2013 Tentang Pedoman Kesesuaian Lahan Pada Komoditas Tanaman Pangan. Jakarta : Sekretariat Negara

Republik Indonesia. 2011. Peraturan Pemerintah Republik Indonesia Nomor 1 Tahun 2011 Tentang Penetapan dan Alih Fungsi Lahan Pertanian Pangan Berkelanjutan. Jakarta : Sekretariat Negara

Subroto,G., dan Susetyo,C. (2016). Identifikasi VariabelVariabel Penentu Lahan Pertanian Pangan Berkelanjutan di Kabupaten Jombang, Jawa Timur. Jurnal Teknik ITS Vol.5 No.2 hal. C129C133

Syahyuti. (2006). Pembaruan Agraria dan Kebutuhan Lahan Untuk Pembangunan Pertanian : Memadukan Aspek Landreform dengan Aspek Non-Landreform Dalam kebijakan Pembaruan Agraria. Jurnal Analisis Sosial Vol 11 Edisi 1. Hal 123-143. 